\title{
NUTRIENT PROFILE OF INDIAN CLIMBING PERCH, Anabas testudineus
}

\author{
B.N. Paul ${ }^{1^{*}}$, S. Chanda ${ }^{1}$, S. Bhowmick ${ }^{1}$, N. Sridhar ${ }^{2}$, G.S. Saha ${ }^{3}$ and S.S. Giri ${ }^{3}$ \\ ${ }^{1}$ Regional Research Centre of CIFA, P.O. Rahara, Kolkata-700 118, India \\ ${ }^{2}$ Regional Research Centre of CIFA, Hessaraghatta Lake, P.O.: Hessaraghatta \\ Bangalore-560 089, Karnataka, India \\ ${ }^{3}$ Central Institute of Freshwater Aquaculture, Kausalyaganga \\ Bhubaneswar-751002, Odisha, India
}

\begin{abstract}
The proximate composition, fatty acid, amino acid and fat soluble vitamins of Indian climbing perch, Anabas testudineus, locally called "Koi" were assayed in relation to its body weight. The fish samples were collected from different geographical locations and were grouped as small $(10-50 \mathrm{~g})$ and big $(52-150 \mathrm{~g})$ sizes. The proximate composition, essential amino acid (EAA) and non-essential amino acid (NEAA) contents in Koi did not differ significantly between the groups. The monounsaturated fatty acid (MUFA) content was significantly $(P<0.05)$ higher in bigger sized Koi. The polyunsaturated fatty acid (PUFA) content was $23.67 \pm 0.85$ and $13.62 \pm 1.02(\%)$ respectively in the small and big sizes of Koi, while the docosahexaenoic acid (DHA) was significantly higher in small Koi. The vitamin A content was $85.77 \pm 0.35$ and 93.90 \pm 1.34 (I.U./100g) respectively in small and big Koi. Vitamin D content was significantly higher in small Koi compared to big one. Vitamin $\mathrm{E}$ and $\mathrm{K}$ were significantly $(\mathrm{P}<0.05)$ higher in big Koi. The results indicated that Anabas testudineus is a good source of protein, fat, vitamins, amino acids and fatty acids.
\end{abstract}

Keywords: Anabas testudineus, Proximate composition, vitamins, amino acid profile and fatty acid profile

\section{INTRODUCTION}

Fish protein occupies an important position in human nutrition (Nargis 2006). Fish is consumed by human being for centuries and is preferred as a perfect diet not only due to its taste and high digestibility but also because of having higher proportions of unsaturated fatty acids, essential amino acids and vitamins and minerals (Kumar, 1992). The high nutritional value of fish is mainly related to their readily digested proteins which are good source of essential amino acid (Mohanty et

*Corresponding author email: bnpaulcifa@gmail.com

Received: 19.03.2017 
al., 2014). Fish is also a good source of polyunsaturated fatty acids (PUFAs), viz., the $\omega-3$ and $\omega-6$ PUFAs, which are well known for beneficial effect to human health (Das et al., 2009; Paul et al., 2015; Mohanty et al., 2016 and Giri et al., 2010). Fatsoluble vitamins viz., Vitamin A, D, E and $\mathrm{K}$ act as essential nutrients in important biological processes of the human body (Sau and Paul, 2004).

Anabas testudineus, commonly called as climbing perch or Koi, is a small fish widely distributed throughout south and south-east Asia. This is a highly priced fish owing to its consumer preference compared to carps. There are few reports available on nutrition and aquaculture of A. testudineus (Mukhopadhyay and Paul, 1996; Kumar et al., 2013 and Bungas et al., 2013). Also, not much information is available on the nutrient profile of Indian climbing perch (Wimalasena and Jayasuriya 1996 and Bogard et al., 2015). Keeping in view the importance as food fish; the nutrient profile of Indian climbing perch, A. testudineus was determined to document the information of amino acid and fatty acid profiles, along with some selected vitamins.

\section{MATERIALS AND METHODS}

\section{Collection of samples}

The samples of Anabas testudineus $(\mathrm{n}=40)$ were collected from West Bengal, Odisha and Andhra Pradesh. The collected fish samples were categorized into two groups as per their bodyweight i.e., small $(10-50 \mathrm{~g})$ and big $(52-150 \mathrm{~g})$. The fish samples were eviscerated and the head was removed. The representative portion of the edible part was taken and homogenized in a mixer for further analysis as per the methodology reported earlier (Sankar et al., 2010). The proximate composition of fish tissue samples was done as per AOAC (2005).

\section{Fatty acid analysis}

Pooled samples were extracted for fatty acid analysis following the method of Folch et al. (1957) using chloroform: methanol (2:1, v/v) solvent system that contained $0.01 \%$ butylated hydroxyl anisole as an antioxidant. Fatty acid methyl esters (FAMEs) were prepared by the transmethylation with boron trifluoride $\left(\mathrm{BF}_{3}\right)$ in methanol from lipids fraction as per Metcalfe et al. (1966). The fatty acid methyl esters were quantified by injecting $1 \mu \mathrm{L}$ (50:1 split ratio) into a gas chromatograph (GC) (Perkin Elmer; CLARUS 480). The oven temperature was programmed from an initial temperature at $30^{\circ} \mathrm{C}$ rising to $140^{\circ} \mathrm{C}$ (hold time $4 \mathrm{~min}$.) and up to $200^{\circ} \mathrm{C}$. Nitrogen gas was used as a carrier gas. The injection port and the flame ionization detector were maintained at 260 and $300^{\circ} \mathrm{C}$. Identification of individual FA was identified by comparison of retention times to those of standards (SUPELCO, Cat. No. 47885-U) and quantified by comparing with respective areas, following "Total Chrome" software of Perkin Elmer.

\section{Amino acid analysis}

The amino acid analysis was done as per the method of Ishida et al., (1981) and Paul et al. (2016a). For amino-acid analysis phenylisothiocyanate (PITC) was used 
for pre-column derivatization, while reversed-phase gradient elution highperformance liquid chromatography (HPLC) separates the phenylthiocarbamyl (PTC) derivatives which are detected by their UV absorbance of Pico Tag method of Waters Associates.

\section{Vitamin analysis}

The fat soluble vitamins Retinol (Vitamin A), Cholecalciferol (Vitamin D), $\alpha$ Tocopherol (Vitamin E) and Vitamin K were analyzed in high performance liquid chromatography system. Fish tissue $(30 \mathrm{~g})$ was grinded with anhydrous sodium sulfate. Then extracted the oil using 2:1 chloroform: methanol after adding BHA as antioxidants (Folch et al., 1957). The sample preparation and vitamin analysis was done as per Sankar et al. (2010). To about $2.0 \mathrm{~g}$ oil in a round bottom flask, added 25 $\mathrm{ml}$ alcohol, and $1.5 \mathrm{ml}$ of $150 \% \mathrm{KOH}$. Reflux in water bath for $30 \mathrm{~min}$. Transfer the contents in to a $250 \mathrm{ml}$ separating funnel after cooling; wash the flask with $50 \mathrm{ml}$ petroleum ether and add to the separating funnel; shake the contents thoroughly and allowed to separate. Extract the aqueous layer twice more and pool the solvent layer. Wash the solvent layer with $20 \%$ of water $(\mathrm{v} / \mathrm{v})$ to make it alkali free. Concentrate non-saponifiable matter in the ether extract fraction using a flash evaporator at $30-40^{\circ}$ $\mathrm{C}$ to a definite volume. The non safonifiable matter is filtered through $0.45 \mu$ syringe filter and stored under refrigerator. Then the fat soluble vitamins were analyzed by injecting $20 \mu \mathrm{L}$ of sample in HPLC equipped with $\mathrm{C}_{18}$ Bondapack column. The mobile phase of HPLC consists of water (HPLC grade) solvent A and acetonitrile as solvent B with $1 \%$ TFA. A gradient system was used (solvent A/solvent B), starting from $50 / 50,80 / 20$ to $100 / 0$ at the rate of $1 \mathrm{~mL} / \mathrm{min}$ for $20 \mathrm{~min}$. The fat soluble vitamins were identified and quantified by comparing with the retention times and peak area of respective vitamins standards.

The data were analyzed using t-test as per Snedecor and Cochran (1968) and have been presented as Mean \pm S.E.

\section{RESULTS AND DISCUSSION}

The proximate composition of Koi is presented in table 1. The moisture, crude protein, crude fat and ash content did not differ significantly between the size groups. The protein and fat content were $16.47 \pm 0.11$ and $16.91 \pm 0.59 ; 6.68 \pm 1.35$ and $6.98 \pm 1.49(\%)$, respectively in small and big Koi. The moisture content of Koi in the present study was lower than the freshwater Eel (Mastacembelus armatus) and Anguila bengalensis bengalensis as reported by Pal and Ghosh (2013). Fat content of Koi was higher in the present study in comparison to that of many freshwater fish species (Pal and Ghosh, 2013; Swapna et al., 2010, Ackman, 2002 and Paul et al., 2016b). Fat content of Koi of the present study is in agreement with earlier report by Nargis (2006). The protein content of Koi was lower than other freshwater fish (Pal and Ghosh, 2013). Generally an inverse relationship between tissue moisture and lipid content is observed with the increase of age and body weight of fish (Wheeler 
and Morrissey, 2003; Jankowska et al., 2007), which was not observed in the present case. The amino acid contents of Koi of two weight ranges are presented in table 2. The essential amino acid contents (EAA) are $44.67 \pm 1.79$ and $44.65 \pm 1.54 \mathrm{~g} / 100 \mathrm{~g}$ whole body protein, respectively in small and big size groups. The Leucine content was maximum among EAA. The non essential amino acid (NEAA) content was $54.48 \pm 0.26$ and $55.80 \pm 0.91 \mathrm{~g} / 100 \mathrm{~g}$ protein, respectively in small and big size of Koi; where Glycine was maximum among NEAA in small size range group. However both the groups contain a good proportion of the essential as well as non-essential amino acids with non significant mean values.

Table 1. Proximate composition (\% as such basis) of Koi (Anabas testudineus) of different body size.

\begin{tabular}{|l|l|l|}
\hline Particulars & Small & Big \\
\hline Moisture & $68.65 \pm 0.68$ & $68.00 \pm 1.77$ \\
\hline Crude Protein & $16.47 \pm 0.11$ & $16.91 \pm 0.59$ \\
\hline Crude Fat & $6.68 \pm 1.35$ & $6.98 \pm 1.49$ \\
\hline Ash & $5.03 \pm 0.04$ & $5.50 \pm 0.49$ \\
\hline
\end{tabular}

Data are presented as Mean \pm S.E. $(n=50)$

The present study for the amino acid content of Koi shows that Isoleucine, Leucine, Valine and Phenylalanine among the essential amino acids (EAA) and Aspartate, Glutamine, Glycine and Alanine among the non essential amino acids (NEAA) are higher in quantity. However, Iwasake and Harada (1985) reported that the main amino acids of fish are Aspartate, Glutamate and Lysine. Over the last 20 years, increasing evidence suggests the importance of Glutamine for the proper functioning of many organ systems (Christina et al., 1999). Our study denotes that Koi of both sizes contain glutamine about 13.14-14.41 (\%) which is very effective for human health. It is observed that the EAA/NEAA ratio is 0.82 and 0.80 in the small and big Koi. Wessilinova (2000) reported the variation in amino acid content of fish with season and location. However, in this study there was no significant variation between the two size groups of Koi.

The fat soluble vitamin content in Koi of different body weights are presented in table 3. The vitamin A content was85.77 \pm 0.35 and $93.90 \pm 1.34(\mathrm{I} . \mathrm{U} / 100 \mathrm{~g})$ in two weight groups, which did not differ significantly. The vitamin D content in Koi is significantly $(\mathrm{P}<0.05)$ higher in smaller Koi. The Koi of bigger size $(50-152 \mathrm{~g})$ contains significantly higher vitamin E (1.27 I.U/100g) and vitamin K (1.15 $\mu \mathrm{g} / 100 \mathrm{~g})$ than the Koi of smaller size. 
Table 2. Amino acid profile (g/100g protein) of Koi (Anabas testudineus) of different body weights

\begin{tabular}{|l|l|l|}
\hline \multicolumn{2}{|l|}{ Particulars } & \multicolumn{2}{l|}{ Small } & \multicolumn{1}{l|}{ Big } \\
\hline Essential Amino Acids (EAA) & $2.10 \pm 0.32$ & $2.01 \pm 0.29$ \\
\hline Arg & $3.99 \pm 0.44$ & $4.12 \pm 0.39$ \\
\hline His & $5.36 \pm 0.10$ & $5.58 \pm 0.46$ \\
\hline Ile & $8.13 \pm 0.25$ & $8.42 \pm 0.66$ \\
\hline Leu & $3.02 \pm 0.40$ & $2.53 \pm 0.24$ \\
\hline Lys & $1.60 \pm 0.06$ & $1.44 \pm 0.05$ \\
\hline Met & $6.26 \pm 0.29$ & $5.95 \pm 0.31$ \\
\hline Phe & $5.48 \pm 0.46$ & $5.88 \pm 0.23$ \\
\hline Thr & $1.39 \pm 0.50$ & $1.09 \pm 0.08$ \\
\hline Try & $7.32 \pm 0.06$ & $7.61 \pm 0.28$ \\
\hline Val & $44.67 \pm 1.79$ & $44.65 \pm 1.54$ \\
\hline EEAA & $10.84 \pm 0.69$ & $10.95 \pm 0.38$ \\
\hline Non-Essential Amino Acids (NEAA) & \\
\hline Asp & $5.07 \pm 0.43$ & $5.30 \pm 0.13$ \\
\hline Ser & $13.14 \pm 0.07$ & $14.41 \pm 0.30$ \\
\hline Glu & $1.63 \pm 0.32$ & $1.42 \pm 0.03$ \\
\hline Pro & $15.29 \pm 0.56$ & $14.90 \pm 0.18$ \\
\hline Gly & $7.26 \pm 0.44$ & $7.77 \pm 0.96$ \\
\hline Ala & $0.22 \pm 0.07$ & $0.14 \pm 0.00$ \\
\hline Cys & $1.01 \pm 0.07$ & $0.89 \pm 0.38$ \\
\hline Tyr & $54.48 \pm 0.26$ & $55.80 \pm 0.91$ \\
\hline ENEAA & 0.82 & 0.80 \\
\hline EAA/NEAA & \multicolumn{1}{|l|}{} \\
\hline
\end{tabular}

Data are presented as Mean \pm S.E. $(n=8)$

Fish is a good source of fat soluble vitamins. Vitamin A content from fish is more readily available to the body than from plant sources (Liu, 2003). Vitamin A is responsible for normal vision and bone growth is well known and its derivative retinoic acid regulates gene expression in the development of epithelial tissue (Roos et al., 2003). Vitamin D functions to activate the innate and dampen the adaptive immune systems (Hewison, 2011). As Koi contains a good amount of vitamin D, it plays a major role for immune system. Vitamin $\mathrm{E}$ is an indispensable nutrient 
required to maintain flesh quality, immunity, normal resistance of red blood corpuscles to haemolysis, permeability of capillaries and heart muscles (Halver and Hardy, 2002). Vitamin E content in Koi ranges from 0.70-1.27 (I.U/100g). The Koi contains 0.53-1.15 $(\mu \mathrm{g} / 100 \mathrm{~g})$ of vitamin K. Vitamin E also functions as lipid soluble antioxidants and protects biological membranes, lipoproteins and lipids against oxidation (Hamre, 1998 and Sau et al., 2004). The human body needs vitamin K for post translational modifications of certain proteins required for blood coagulation and in metabolic pathways in bone and other tissue (Halver and Hardy, 2002).

Table 3. Vitamin content of Koi (Anabas testudineus) of different body weights

\begin{tabular}{|l|l|l|}
\hline Particulars & Small & Big \\
\hline A (I.U/100g) & $85.77 \pm 0.35$ & $93.90 \pm 1.34$ \\
\hline D (I.U/100g) & $85.60^{\mathrm{b}} \pm 1.29$ & $43.12^{\mathrm{a}} \pm 1.03$ \\
\hline E (I.U/100g) & $0.70^{\mathrm{a}} \pm 0.04$ & $1.27^{\mathrm{b}} \pm 0.03$ \\
\hline K $(\mu \mathrm{g} / 100 \mathrm{~g})$ & $0.53^{\mathrm{a}} \pm 0.03$ & $1.15^{\mathrm{b}} \pm 0.02$ \\
\hline
\end{tabular}

Superscript ${ }^{\mathrm{a}, \mathrm{b}}$ in a row differs significantly $(\mathrm{P}<0.05)$. Data are presented as Mean \pm S.E. $(\mathrm{n}=8)$

The fatty acid profile of Koi is presented in table 4 . The saturated fatty acids (SFA) were $66.19 \pm 3.33$ and $60.73 \pm 1.25(\%)$ respectively in small and big Koi. Among SFA the palmitic and stearic acid are found to be higher in both the groups. The palmitic acid is significantly $(\mathrm{P}<0.05)$ higher in big Koi compared to small one; conversely stearic acid was higher in small Koi than big one. Other SFAs viz., pentadecanoic, heptadecanoic and arachidonic acid were significantly $(\mathrm{P}<0.05)$ higher in small size of Koi.

The monounsaturated fatty acid (MUFA) contents were $10.39 \pm 0.51$ and $25.70 \pm 0.89$ respectively in small and big groups. Palmitoleic acid was significantly $(\mathrm{P}<0.05)$ higher in big size of Koi. The MUFA content is significantly $(\mathrm{P}<0.05)$ higher in big Koi. The polyunsaturated fatty acids (PUFA) are $23.67 \pm 0.85$ and $13.62 \pm 1.02$ respectively in the small and big koi. The PUFA content is significantly higher in small group compared to the bigger group. Among PUFA, $\alpha$-linolenic acid is significantly $(\mathrm{P}<0.05)$ higher in small Koi. The docosahexaenoic acid (DHA) is also significantly $(\mathrm{P}<0.05)$ higher in smaller group. $\Sigma \omega 3$ PUFA are significantly $(\mathrm{P}<0.05)$ higher in smaller Koi but $\Sigma \omega 6$ PUFA are significantly $(\mathrm{P}<0.05)$ higher in the bigger size of Koi. It is also observed that SFA and MUFA are higher in bigger sized Koi whereas the PUFA content is higher in Koi of smaller size.

Fatty acid composition of aquatic animals is influenced by intrinsic variables, such as species, sex, age and size; as well as extrinsic factors, such as diet, salinity, temperature, geographical regions, and the general rearing conditions (Abd Rahman 
Table 4. Fatty acid profile (\% of total fatty acid) of Koi (Anabas testudineus) of different body weights

\begin{tabular}{|l|c|c|}
\hline \multicolumn{1}{|c|}{ Particulars } & Small & Big \\
\hline C12:0 (Lauric Acid) & $0.43 \pm 0.03$ & $0.68 \pm 0.05$ \\
\hline C14:0 (Myristic Acid) & $1.33 \pm 0.18$ & $1.35 \pm 0.13$ \\
\hline C15:0 (Pentadeconoic Acid) & $1.27^{\mathrm{b}} \pm 0.08$ & $0.48^{\mathrm{a}} \pm 0.09$ \\
\hline C16:0 (Palmitic Acid) & $40.56^{\mathrm{a}} \pm 1.60$ & $52.56^{\mathrm{b}} \pm 2.12$ \\
\hline C17:0 (Heptadeconoic Acid) & $2.70^{\mathrm{b}} \pm 0.28$ & $0.11^{\mathrm{a}} \pm 0.02$ \\
\hline C18:0 (Stearic Acid) & $15.32^{\mathrm{b}} \pm 2.04$ & $5.19^{\mathrm{a}} \pm 0.64$ \\
\hline C20:0 (Arachidic Acid) & $0.71^{\mathrm{b}} \pm 0.06$ & $0.31^{\mathrm{a}} \pm 0.03$ \\
\hline C21:0 (Heneicosanoic Acid) & $3.21 \pm 0.21$ & $\mathrm{ND}$ \\
\hline Other & $0.66^{\mathrm{b}} \pm 0.03$ & $0.05^{\mathrm{a}} \pm 0.01$ \\
\hline$\Sigma$ SFA & $66.19 \pm 3.33$ & $60.73 \pm 1.25$ \\
\hline C15:1 (Pentadecenoic Acid) & $0.51 \pm 0.03$ & $0.91 \pm 0.06$ \\
\hline C16:1 (Palmitoleic Acid) & $8.56^{\mathrm{b}} \pm 0.46$ & $3.27^{\mathrm{a}} \pm 0.18$ \\
\hline C17:1 (Heptadeconoic Acid) & $0.66 \pm 0.05$ & $0.46 \pm 0.11$ \\
\hline C18:1n9c (Oleic Acid) & $\mathrm{ND}$ & $2.49 \pm 0.11$ \\
\hline C18:1n9t (Elaidic Acid) & $\mathrm{ND}$ & $18.13 \pm 0.88$ \\
\hline C20:1n9 (Eicisanoic Acid) & $0.66 \pm 0.03$ & $0.44 \pm 0.05$ \\
\hline$\Sigma$ MUFA & $10.39^{\mathrm{a}} \pm 0.51$ & $25.70^{\mathrm{b}} \pm 0.89$ \\
\hline C18:2n6c (Linoleic Acid) & $\mathrm{ND}^{\mathrm{b}}$ & $8.17 \pm 0.96$ \\
\hline C18:3n3( $\alpha$ Linolenic Acid) & $17.83^{\mathrm{b}} \pm 0.85$ & $1.91^{\mathrm{a}} \pm 0.06$ \\
\hline C18:3n6 ( $\gamma$ Linolenic Acid) & $0.37 \pm 0.04$ & $0.11 \pm 0.01$ \\
\hline C20:4n6 (Arachidonic Acid) & $1.24 \pm 0.11$ & $\mathrm{ND}$ \\
\hline C20:5n3 (Eicosapenta enoic Acid) & $0.38 \pm 0.04$ & $\mathrm{ND}$ \\
\hline C22:6n3 (Docosahexaenoic Acid) & $2.67^{\mathrm{b}} \pm 0.16$ & $1.26^{\mathrm{a}} \pm 0.07$ \\
\hline Other & $1.18 \pm 0.09$ & $2.18 \pm 0.11$ \\
\hline$\Sigma$ PUFA & $23.67^{\mathrm{b}} \pm 0.85^{\mathrm{b}}$ & $13.62^{\mathrm{a}} \pm 1.02$ \\
\hline$\Sigma \omega-3$ PUFA & $20.88^{\mathrm{b}} \pm 0.66$ & $4.11^{\mathrm{a}} \pm 0.03$ \\
\hline$\Sigma \omega-6$ PUFA & $1.61^{\mathrm{a}} \pm 0.12$ & $8.30^{\mathrm{b}} \pm 0.20$ \\
\hline$\omega-3: \omega-6$ PUFA & $1.16^{\mathrm{b}} \pm 0.12$ & $0.49^{\mathrm{a}} \pm 0.02$ \\
\hline
\end{tabular}

Superscript in row ${ }^{\mathrm{a}, \mathrm{b}}$ differs significantly $(\mathrm{P}<0.05)$. Data are represented as Mean \pm S.E. $(\mathrm{n}=8)$ 
et al., 1995; Sener et al., 2005). Fatty acids in fishes are derived from two main sources, namely, biosynthesis and diet (Hearn et al., 1987, Morris et al., 1995, Kamler et al., 2001). Palmitic acid content among the SFA is maximum in big size Koi which is in agreement with earlier report (Kaya et al., 2008). The SFA content is higher in freshwater fish (Indian Major Carp) as reported by Paul et al., (2015) which is in agreement with the present result. The palmitic acid is considered to be a key to many metabolic processes in fish and other aquatic animals (Ackman and Eaton, 1966). Fish oils are known to be rich source of essential PUFA of the omega-3 family (Kenari et al., 2009). In Koi PUFA content varies from 13.62-23.67\% and DHA ranges from 1.26-2.67\%. This is in agreement with earlier report (Kenari et al., 2009). The n-3 PUFAs, especially the eicosapentaenoic acid (EPA) and docosahexaenoic acid (DHA) are found in high concentrations in the phosphoglycerides of cellular membranes, and DHA is particularly abundant in the retina and brain, where it has a crucial role in maintaining the structure and function of the excitable membranes of these tissues (Lauritzen et al., 2001). These fatty acids have beneficial effect in the prevention of cardiovascular and inflammatory diseases (Gebauer et al., 2006) and neurodegenerative syndromes, such as Alzheimer's disease (Moyad, 2005). The consumption of fish and fish oils containing omega-3 fatty acids are beneficial for a number of biological factors like cardiovascular diseases, rheumatoid arthritis, psoriasis (Paul et al., 2016a).

\section{CONCLUSION}

The results indicated that Koi is a good source of essential amino acids, protein, fat and ash. Among the fatty acids, palmitic and stearic acid were dominant in SFA and palmitoleic acid was predominant in MUFA. Among the PUFA, linolenic and docosahexaenoic acids were found in higher contents. Vitamin A and D were also present in good quantity in Koi. Irrespective of the size groups, the nutrient profile reflected that the fish was enriched with fat, protein, fatty acids, essential amino acids and vitamins.

\section{ACKNOWLEDGEMENT}

This work was supported by Ministry of Agriculture, Government of India under ICAR Outreach Activity on Nutrient Profiling and Evaluation of fish as a Dietary component. The authors greatly acknowledge the help of DDG (Fy, ICAR) and Director, CIFA for providing necessary support and facility to conduct the work.

\section{REFERENCES}

Abd Rahman, S., Osman, T.S.H., Hassan, O. and Daud, N.M. 1995. Fatty acid composition of some Malaysian fresh water fish. Food Chemistry, 54: 45-49

Ackman, G.G. and Eaton, C.A. 1966. Some commercial Atlantic herring oils fatty acid composition. Journal of Fishery Research Board of Canada, 23 (7): 991-1006 
Ackman, R.G. 2002. Lipid and fatty acids of five freshwater food fishes of India. Journal of Food Lipids, 9: 127-145

AOAC. 2005. Official methods of Analysis, $18^{\text {th }}$ edition. Association of Official Analytical Chemists, Washington. DC

Bogard, J.R., Thilsted, S.H., Marks, G.G., Wahab, M.A., Hossain, M.A.R., Jakobsen, J. and Stangoulis, J. 2015. Nutrient composition of important fish species in Bangladesh and potential contribution to recommended nutrient intakes. Journal of Food Composition and Analysis, 42: 120-133

Bungas, K., Arfiati, D., Marsoedi. And Halim, H. 2013. Effects of Protein Levels on the Growth of Climbing Perch, Anabas testudineus Galam type, in Peat Water. International Research Journal of Biological Sciences, 2(4): 55-58

Christina, J., Palmer, A., and Griffiths, R.D. 1999. Randomized clinical outcome study of critically ill patients given glutamine supplemented eternal nutrition. Nutrition, 15:108115

Das, S., Paul, B.N., Sengupta, J. and Datta, A.K. 2009. Beneficial effects of fish oil to human health: A Review. Agricultural Reviews, 30 (3)199-205

Folch, J., Less, M., and Stanley, G.H.S.1957. A simple method for the isolation and purification of total lipids from animal tissues. Journal of Biochemistry, 226: 497-509

Gebauer, K., Psota, T.L., Harris, W.S. and Kris-Eterton, P.M. 2006. n-3 Fatty acid dietary recommendations and food sources to achieve essentiality and cardiovascular benefits. American Journal of Clinical Nutrition, 83: S1526-S1535

Giri, S.S., Paul, B.N., Sahoo, S.K., Rangacharyulu, P.V., Rath, S.C., and Mohanty, S.N. 2010. Fish oils and cardio vascular health. Fishing Chimes, 30(2): 37-39

Halver, J.E. 2002. The vitamins p. 61-141. in Halver, J.E. and Hardy, R.W. (eds.) Fish Nutrition. Academic Press, San Diego

Hamre, K., Berge, R.K. and Lie, O. 1998. Turnover of $\alpha$-, $\gamma$-, and $\delta$-tocopherol and distribution in subcellular and lipoprotein fractions indicate presence of and hepatic tocopherol binding protein in Atlantic salmon (Salmo salar L.). Fish Physiology and Biochemistry, 18: 71-83

Hearn, T.L., Sgoutas, S.A., Hearn, J.A. and Sgoutas, D.S. 1987. Polyunsaturated Fatty Acids and fat in fish flesh for selecting species for health benefits. Journal of Food Science, 52(5): 1209-11

Hewison, M. 2011. Vitamin D and innate and adaptive immunity. Vitamins and Hormones, 86: 23-62

Ishida, Y., Fujita, T. and Asai, K. 1981. New detection and separation method for amino acids by high-performance liquid chromatography. Journal of Chromatography, 204: 143148

Iwasaki., M. and Harada, R. 1985. Proximate and amino acid composition of the roe and muscle of selected marine species. Journal of Food Science, 50: 1585-1587

Jankowska, B., Zakes, Z., Zmijewski, T., Szczepkowski, M., and Kowalska, A. 2007. Slaughter yield, proximate composition, and flesh colour of cultivated and wild perch (Perca fluviatilis L.). Food Chemistry, 118: 764-768 
Kamler, E., Krasicka, B. and Rakusa-Suszczewski, S. 2001. Comparison of Lipid content and fatty acid composition in muscle and liver of two notothenoid fishes from Admiralty Bay (Antartica), and eco-physiological perspective. Polar Biology, 24: 735-743

Kaya, Y., Turan, H. and Erdem, M.E. 2008. Fatty acid and amino acid composition of raw and hot smoked sturgeon (Huso huso L. 1758). International Journal of Food Science and Nutrition, 59(7-8): 635-642

Kenari, A.A., Regenstein, J.M., Rezai, M., Tahergorabi, R., Nazari, R. M., Mogaddasi, M. and Kaboli, S.A. 2009. Amino acid and fatty acid composition of cultured Beluga (Huso huso) of different ages. Journal of Aquatic Food Product Technology, 18: 245265

Kumar, K., Sarma, S., Chakrabarti, P.P., Kumar, R., Mohanty, U.L., Sahoo, M., Mohanty, A.K., Sahoo, A.K. and Jayasankar, P. 2013. Anabas (Koi) farming in Sonapur, Assam: A successful demonstration. Fishing Chimes, 33(182): 136-137

Kumar, D. 1992. Fish culture in Un-drainable ponds. A manual for extension FAO Fisheries Technical paper, No. 235:239

Lauritzen, L., Hansen, H.S., Jorgensen, M.H. and Michaelsen, K.F. 2001. The essential of long chain $n-3$ fatty acid in relation to development and function of the brain and retina. Progress in Lipid Research, 40: 1-94

Metcalfe, L.D., Schmitz, A.A. and Petha, J.R. 1996. Rapid preparation of fatty acid esters from lipids for gas chromatographic analysis. Analytical Chemistry, 38: 514

Mohanty, B.P., Mahanty, A., Ganguly, S., Sankar, T.V., Chakraborty,K., Anandan, R., Paul, B.N., Sarma, D., Mathew, S., Asha, K.K., Behera, B.K., Afftabuddin, M., Debnath, D., Vijaygopal, P., Sridhar, N., Akhtar, M.S., Sahi, N., Mitra, T., Banerjee, S., Paria, P., Das, D., Das, P., Vijayan, K.K., Lamanan, P.T. and Sharma, A.P. 2014.Amino Acid composition of 27 Food fishes and their importance in Clinical Nutrition. Journal of Amino Acid, 1: 1-7. Doi.org/10.1155/2014/269797

Mohanty, B.P., Ganguly, S., Mahanty, A., Sankar, T.V., Anandan, R. Chakraborty, K., Paul, B.N., Sarma, D., Dayal, J.S., Venkateshwarlu, G., Mathew, S., Asha, K.K., Karunakaran, D., Mitra, T., Banerjee, S., Chanda, S., Shahi, N., Das, P., Akhtar, M.S., Vijayagopal, P., Sridhar, N. 2016. DHA, EPA content and Fatty acid Profile of 39 Food Fishes from India. Biomedical Research International. Doi. 10. $1155 / 2016 / 4027437$

Morris, M.C., Manson, J.E. and Rosner, B.1995. Fish consumption and cardiovascular disease in the Physicians' Health Study: a prospective study. American Journal of Epidemiology, 142: 166-175

Moyad, M.A. 2005. An introduction to dietary/supplemental omega-3 fatty acids for general health and prevention: Part II. Urologic Oncology, 23: 36-48

Mukhopadhyay, P.K. and Paul, B.N. 1996. Values addition components in Aquaculture feeds. Fishing Chimes, 6: 15-16

Nargis, A. 2006. Seasonal variation in the chemical composition of body flesh of Koi fish, Anabas testudineus (Bloch), (Anabantidae: Perciformes). Bangladesh Journal of Scientific and Industrial Research, 41: 219-226 
Pal, M., and Ghosh, M. 2013. Assay of Biochemical Compositions of two Indian freshwater Eel with special emphasis on accumulation of toxic heavy metals. Journal of Aquatic Food Product and Technology, 22: 27-35

Paul, B.N., Chanda, S., Sridhar, N., Saha, G.S. and Giri, S.S. 2015. Fatty acid profile of Indian Major Carp. Indian Journal of Animal Nutrition, 32(2): 221-226

Paul, B.N., Chanda, S., Sridhar, N. and Giri, S.S. 2016. Nutrient profile of some freshwater food fishes and its significance as health food. N. Kewalramani, N. Tyagi, G, Mondal, S. Kumar, C. Datt, S.S. Kundu and S.K. Tomar (Eds.). Innovative Approaches for Animal Feeding and Nutritional Research. Invited Papers of XVI Biennial Animal Nutrition Conference, February 6-8, 2016, Karnal, India, 372 pp

Paul, B.N., Chanda, S., Sridhar, N., Saha, G.S and Giri, S.S. 2016a. Fatty acid, Amino acid and Vitamin composition of Indian Catfish, Magur (Clarias batrachus) and Singhi (Heteropneustes fossilis). SAARC Journal of Agriculture, 14(2): 189-199. Doi./org/10.3329/sja.v14i2.31258

Paul, B.N., Chanda, S., Sridhar, N., Saha, G.S. and Giri, S.S. 2016b. Proximate, mineral and vitamin contents of Indian Major Carp. Indian Journal of Animal Nutrition, 33(1): 102107. doi: $10.5958 / 2231-6744.2016 .00018 .9$

Roos, N., Islam, M.M. and Thilsted, S.H. 2003. Small fish is an important dietary source of vitamin A and Calcium in Bangladesh. Journal of Nutrition, 133: 4021S-4026S

Sankar, T.V., Susheela, M., Anandan, R., Asha, K.K. and Mohanty, B.P. 2010. Nutrient Profiling of Fish. Central Institute of Fisheries Technology, Indian Council of Agricultural Research, pp. 61

Sau, S.K., Paul, B.N., Mohanta, K.N. and Mohanty, S.N. 2004. Dietary vitamin E requirement, fish performance and carcass composition of rohu (Labeo rohita) fry. Aquaculture, 240: 359-368

Sau, S.K. and Paul, B.N. 2004. Over view of fat soluble vitamins in Aquaculture. Fishing Chimes, 24(7): 28-30

Sener, E., Yildiz, M. and Savas, E. 2005. Effects of dietary lipids on growth and fatty acid composition in Russian sturgeon (Acipenser gueldenstaedtii) juveniles. Turkish Journal of Veterinary and Animal Science, 29: 1101-1107

Snedecor, G.W. and Cochran, W.G. 1968. Statistical Methods. $6^{\text {th }}$ ed. Oxford and IBH Publishing Company, Calcutta, India

Swapna, H.C., Rai, A.K., Bhaskar, N., and Sachindra, N.M. 2010. Lipid classes and fatty acid profile of selected Indian fresh water fishes. Journal of Food Science and Technology, 47: 394-400

Wessilinova, D. 2000. Amino acid composition of Fish meat after different frozen storage periods. Journal of Aquatic Food Product Technology, 9: 41-48

Wheeler, S., and Morrissey, M.T. 2003. Quantification and distribution of lipid, moisture and fatty acids of west coast Albacore tuna (Thunnus alalunga). Journal of Aquatic Food Product Technology, 12: 3-16

Wimalasena, S. and Jayasuriya, M.N.S. 1996. Nutrient analysis of some freshwater fish. Journal of the National Science Council of Sri Lanka, 24(1): 21-26 